\title{
Analisis Prediksi Kebangkrutan pada Perusahaan Manufaktur Sub Sektor Food \& Beverages Yang Terdaftar di Bursa Efek Indonesia: Menggunakan Model Altman, Springate, dan Grover
}

\author{
Widia Nasmi ${ }^{1 *}$, Mayar Afriyenti ${ }^{2}$ \\ ${ }^{1,2}$ Fakultas Ekonomi, Universitas Negeri Padang \\ *Korespondensi: yolafionita199@gmail.com
}

\begin{abstract}
The objective of this research is to determine (1) the prediction of bankruptcy of manufacturing companies in the food and beverages sub-sector listed on the Indonesia Stock Exchange by using the Altman, Springate and Grover models in the 2016 to 2019 period, and (2) to find out the differences in the results of bankruptcy predictions, and also to determine the level of accuracy of the five models in predicting bankruptcy. Sampling method used Purposive Sampling with some criterias which produce 14 samples of food and beverages firms for 5 years of data observation. The results indicate that, first, by using the Altman models, it is predicted that two companies will experience bankruptcy. Altman model and Grover model predict three companies to go bankrupt, while the Springate model predicts four companies to go bankrupt. Second, there is no significant difference between the Altman, Springate and Grover models in predicting the bankruptcy rate of food and beverages subsector companies listed on the Indonesia Stock Exchange. Third, the Springate model is a model that has the highest level of accuracy in predicting the bankruptcy of the food and beverages sub-sector, which has an accuracy rate of $92.86 \%$.
\end{abstract}

Keywords: Bankruptcy; Altman model; Springate model; Grover model.

How to cite (APA $6^{\text {th }}$ style)

Widia, Nasmi \& Afriyenti, Mayar. (2021). Analisis Prediksi Kebangkrutan pada Perusahaan Manufaktur Sub Sektor Food \$ Beverages Yang Terdaftar di Bursa Efek Indonesia: Menggunakan Model Altman, Springate, dan Grover. Jurnal Eksplorasi Akuntansi (JEA), 3 (4), 749-763.

\section{PENDAHULUAN}

Industri food and beverages merupakan salah satu industri yang memiliki peranan penting dan memiliki pengaruh terhadap pertumbuhan perekonomian di Indonesia. Kementrian Perindustrian Republik Indonesia (2020) mencatat industri food and beverages merupakan sektor yang berkontribusi cukup besar terhadap perekonomian nasional. Sektor food and beverages memberikan kontribusi sebesar 36,4 persen terhadap Produk Domestik Bruto (PDB) manufaktur. Menteri Perindustrian Agus Gumiwang Kartasasmita menegaskan bahwa, industri food and beverages adalah salah satu sektor yang dijadikan andalan penopang pertumbuhan manufaktur dan ekonomi nasional. Industri food and beverages yang memiliki peranan penting bagi pertumbuhan, sehingga Kementrian Perindustrian Republik 
Indonesia terus melakukan upaya-upaya yang dapat mendorong pengembangan sektor industri food and beverages di tanah air (Kemenperin, 2015).

Namun pada kenyataannya masih banyak terdapat perusahaan yang masih belum mampu untuk bersaing dan berkembang, bahkan ada yang mengalami kebangkrutan. Kebangkrutan yang terjadi pada perusahaan disebabkan oleh dua faktor yaitu faktor eksternal dan internal. Kebangkrutan disebabkan oleh faktor luar (ekternal) seperti kondisi perekonomian, bencana alam, dan keadaan geografis tertentu. Selanjutnya dipengaruhi oleh faktor internal perusahaan itu sendiri antara lain kesalahan manajemen dalam mengelola hutang, kurangnya kerja sama dalam manajemen perusahaan, dan lain sebagainya.

Salah satu hal yang menjadi pemicu terjadinya kebangkrutan pada perusahaan manufaktur adalah tingkat penjualan yang mengalami penurunan (Sibarani dalam Hadijah dan Kurniasih, 2014:302). Penurunan tingkat penjualan itu sendiri bisa menyebabkan terjadinya penurunan pendapatan perusahaan dan berdampak pada turunnya laba. Diperkuat oleh Hanafi dan Halim dalam Noviandani dan Putri (2018) hal lain yang menjadi pemicu kebangkrutan adalah kesulitan keuangan jangka pendek yang dapat menimbulkan kesulitan yang tidak solvabel. Kesulitan yang tidak solvabel terjadi ketika perusahaan mengalami kesulitan dalam melunasi hutang karena asset yang terbatas. Hal itulah yang menjadi pemicu kebangkrutan perusahaan manufaktur pada sub sektor food and beverages.

Isu negatif sering beredar di tengah masyarakat Indonesia seputar food and beverages (Irawan dalam Hadijah dan Kurniasih, 2014). Isu negatif yang beredar menjelaskan adanya bahan-bahan berbahaya yang terkandung dalam produk food and beverages. Hal inilah yang menjadi pemicu sehingga menurunnya minat konsumen atau masyarakat untuk mengkonsumsi produk tersebut. Akibatnya permintaan atas produk food and beverages akan menurun. Apabila permintaan tersebut menurun, akan berdampak kepada pendapatan perusahaan itu sendiri dan berdampak langsung kurang minatnya masyarakat terhadap produk itu.

Indikasi potensi kebangkrutan dapat dilakukan antisipasi terlebih dahulu sebelum terlambat dengan menggunakan model prediksi yang dapat dijadikan sebagai peringatan awal untuk mengidentifikasi serta memperbaiki kondisi sebelum sampai pada kondisi kebangkrutan total. Berbagai alat prediksi kebangkrutan yang dapat digunakan yakni model Altman Z-score, model Springate dan model Zmijewski. Selain ketiga model tersebut, masih terdapat beberapa model yang digunakan untuk memprediksi kebangkrutan pada perusahaan yakni model Ohson, model Grover, model Fulmer, model CA-Score dan masih banyak lainnya. Sejalan dengan penelitian yang dilakukan oleh Gamayuni (2009:87) bahwa sebagian peneliti menggunakan beberapa model kebangrutan untuk membandingkan keakuratan prediksi antara satu model dengan model analisis lainnya. Serta ada juga peneliti yang menggabungkan beberapa model analisis dengan harapan dapat mengambil berbagai keunggulan yang ada dan mengatasi kelemahan yang ada pada suatu model sehingga menghasilkan tingkat ketepatan prediksi yang lebih tinggi atau dapat memprediksi kebangkrutan perusahaan dengan lebih akurat. Penelitian mengenai model prediksi kebangkrutan sebelumnya sudah banyak dilakukan, umumnya menggunakan model Altman Z-score sementara model lainnya masih jarang digunakan.

Berdasarkan dari yang telah diuraikan diatas, penulis tertarik untuk menganalisa dan mengetahui tingkat kebangkrutan dengan menggunakan model Altman pertama, Altman Revisi, Altman Modifikasi, Springate dan Grover yang dijadikan sebagai alat untuk melakukan analisis potensi kebangkrutan pada perusahaan manufaktur sub sektor food and beverages yang terdaftar di Bursa Efek Indonesia dengan judul Analisis Prediksi Kebangkrutan Pada Perusahaan Manufaktur Sub Sektor Food And Beverages Yang Terdaftar Di Bursa Efek Indonesia Dengan Menggunakan Model Altman Pertama, Altman Revisi, Altman Modifikasi, Springate, Dan Grover. 


\section{KAJIAN TEORI}

\section{Teori Sinyal (Signalling Theory)}

Teori yang digunakan dalam penelitian ini adalah Teori Sinyal (Theory Siganlling) yang dikemukakan oleh Spance (1973) yang menjelaskan bahwa pihak pengirim informasi memberikan suatu sinyal berupa informasi yang bermanfaat dari pihak pemilik informasi kepada pihak penerima informaasi. Teori sinyal menjelaskan bahwa pemberian sinyal dilakukan manajemen untuk mengurangi asimetri informasi. Informasi yang diberikan merupakan unsur yang penting bagi investor dan pemangku kepentingan, karena informasi tersebut memuat tentang keterangan, catatan, gambaran perusahaan dimasa depan dan dimasa lalu (Brigham dan Hauston, 2014).

Keterkaitan teori sinyal dalam penelitian ini adalah jika analisis laporan keuangan dalam memprediksi kebangkrutan dilakukan dan menghasilkan prediksi yang dapat digunakan untuk menjelaskan perusahaan yang dianalisis mengalami potensi kebangkrutan maka perusahaan tersebut mendapat sinyal negatif sehingga akan merugikan investor dan kreditor. Sebaliknya, jika hasil prediksi menghasilak tidak mengalami potensi kebangkrutan maka perusahaan akan memproleh sinyal positif yang bermanfaat bagi investor dan kreditor (Najmi, 2019).

\section{Laporan Keuangan}

Laporan keuangan merupakan laporan yang memberikan gambaran tentang kondisi keuangan perusahaan pada saat ini atau periode tertentu (Kasmir dalam fitri wulandari dkk, 2017:17). Sedangkan menurut Munawir dalam Catarina (2018:8) menyatakan bahwa laporan keuangan adalah alat yang sangat penting untuk mendapatkan informasi yang berkaitan dengan posisi keuangan dan hasil-hasil yang diperoleh oleh perusahaan yang bersangkutan. Laporan keuangan diharapkan dapat memberikan informasi yang akan mempermudah pihakpihak berkepentingan dalam mengambil keputusan ekonomi yang bersifat finansial.

Analisis laporan keuangan merupakan analisis yang berisi penelaahan dan tandensi agar dapat menentukan hasil operasi serta perkembangan perusahaan yang bersangkutan dan posisi keuangan. Analisis laporan keuangan perlu dilakukan secara cermat dengan menggunakan metode dan teknik analisis yang tepat sehingga hasil yang didapat sesuai dengan yang diharapkan (Munawir dalam Riwan dan Kusama, 2014:98). Kemudian hasil perhitungan dianalisis dan diinterpretasikan untuk mengetahui posisi keuangan yang sesungguhnya. Analisis laporan keuangan berfungsi menguraikan pos-pos laporan keuangan menjadi unit informasi yang lebih kecil dan melihat hubungannya yang bersifat signifikan atau yang mempunyai makna antara satu dengan yang lainnya baik antara data kuantitatif maupun data non-kuantitatif dengan tujuan untuk mengetahui kondisi keuangan lebih dalam yang sangat penting dalam proses menghasilkan keputusan yang sangat tepat (Harahap dalam Riwan dan Kusama, 2014:98).

\section{Tujuan Laporan Keuangan}

Analisis Laporan Keuangan memiliki tujuan sebagai berikut (Harahap dalam Salatin dkk, 2013:3).

1. Screening, Analisis yang dilakukan terhadap laporan keuangan untuk membuat pilihan untu melakukan investasi atau merger.

2. Forecasting, Analisis yang dilakukan untuk meramal kondisi keuangann perusahaan dimasa depan.

3. Diagnosis, Analisis yang dilakukan untuk melihat apakah terjadi masalah pada bagianbagian tertentu seperti: manajemen, operasi, keuangan atau masalah lainnya.

4. Evaluation, Analisis yang dilakukan untuk menilai prestasi manajemen, operasional, efisiensi, dan lainnya. 


\section{Analisis Rasio Keuangan}

Analisis rasio keuangan merupakan suatu instrumen analisis prestasi perusahan yang menjelasakan berbagai hubungan serta indikator keuangan, berguna untuk mengetahui perubahan kondisi keuangan perusahaan (Warsidi dan bambang dalam Dewi, 2017:3). Diperkuat oleh Munawir (2010) menjelaskan analisis rasio keuangan merupakan analisis yang memberi gambaran hubungan atau perimabangan antara jumlah tertentu dengan jumlah lain, menggunakan alat yang berupa rasio yang dapat memberi gambaran kepada penganalisa mengenai kondisi keuangan perusahaan terutama ketika angka rasio tersebut dibandingkan dengan angka rasio pembanding yang dijadikan standarnya.

\section{Kebangkrutan}

Kebangkrutan (bankruptcy) merupakan sebagai suatu kondisi dimana suatu entitas dinyatakan tidak mampu untuk melunasi kewajibannya paling tidak satu hutang yang sudah jatuh tempo dan bisa ditagih (Toto dalam Hadijah dan Kurniasih, 2014:303). Kebangkrutan juga dapat diartikan sebagai kegagalan perusahaan dalam beroperasi untuk memproleh laba yang diinginkan. Sedangkan menurut Fahmi dalam Gede et al, (2020:316) menjelaskan bahwa kebangkrutan adalah suatu resiko yang dialami perusahaan disebabkan oleh ketidakmampuannya dalam memenuhi kewajiban jangka pendek, sehingga berdampak pada terganggunya aktifitas perusahaan.

\section{Penanggulangan Potensi Kebangkrutan}

Kondisi kesulitan keuangan (distress) pada perusahaan akan memberi dampak negatif karena menimbulkan kurangnya kepercayaan dari investor, kreditor dan pihak-pihak lainnya terhadap perusahaan. Maka pihak manajemen perusahaan perlu mengambil langkah-langkah untuk menanggulangi permasalahan kesulitan keuangan (distress) sehingga kebangkrutan yang akan terjadi dapat dihindari. Menurut Pustylnick dalam Dwijayanti (2016:203) terdapat dua solusi jika perusahaan mengalami arus kas negatif yaitu, dengan restrukturisasi utang dan perubahan dalam manajemen.

\section{Model-model Prediksi Kebangkrutan Model Altman Pertama}

Model kebangkrutan pertama digunakan untuk memprediksi perusahaan publik manufaktur yang terdaftar pada Bursa Efek Indonesia.

Altman Pertama menggunakan rumus sebagai berikut:

$\mathrm{Z}=1,2 \mathrm{X}_{1}+1,4 \mathrm{X}_{2}+3,3 \mathrm{X}_{3}+0,6 \mathrm{X}_{4}+0,999 \mathrm{X}_{5}$

Keterangan:

$\mathrm{X}_{1}=$ Working Capital / Total asset

$\mathrm{X}_{2}=$ Retained Earnings / Total asset

$\mathrm{X}_{3}=$ Earning Before Interest And Taxes / Total Asset

$\mathrm{X}_{4}=$ Book Value Of Equity / Book Value Of Total Debt

$\mathrm{X}_{5}=$ Sales / Total Asset .

Terdapat angka cut off dari Z-score yang dijadikan patokan untuk menentukan apakah perusahaan berada pada kondisi sehat, pada posisi grey area, atau mengalami kesulitan keuangan (distress). Dari hasil perhitungan Z-score, dapat diklasifikasikan tingkat kesehatan Apabila:

1. Nilai $Z<1,8$ artinya perusahaan mengalami kesulitan keuangan (distress) yang berpotensi mengalami kebangkrutan. 
2. Nilai $1,8<Z<2,99$ artinya perusahaan dalam kondisi grey area sehingga kondisi ini tidak dapat dikatan sehat atupun kesulitan keuangan (distress).

3. Nilai $Z>2,99$ artinya perusahaan dalam kondisi sehat.

\section{Model Altman Revisi (1993)}

Hal yang menjadi pemicu Altman melakukan penelitian kembali di berbagai negara adalah tidak semua perusahaan melakukan go public dan tidak semua perusahaan yang memiliki nilai pasar.

Altman Revisi menggunakan rumus sebagai berikut:

$\mathrm{Z}=0,717 \mathrm{X}_{1}+0,847 \mathrm{X}_{2}+3,108 \mathrm{X}_{3}+0,42 \mathrm{X}_{4}+0,988 \mathrm{X}_{5}$

Keterangan:

$\mathrm{X}_{1}=$ Working Capital / Total Asset

$\mathrm{X}_{2}=$ Retained Earnings / Total Asset

$\mathrm{X}_{3}=$ Earning Before Interest And Taxes / Total Asset

$\mathrm{X}_{4}=$ Book Value Of Equity / Book Value Of Total Debt

$\mathrm{X}_{5}=$ Sales $/$ Total Asset.

Analisa Altman Z-score terbagi menjadi tiga tingkatan. Hasil analisa dengan nilai cut off diperoleh sebagai berikut:

1. Nilai $\mathrm{Z}<1,23$ artinya perusahaan mengalami kesulitan keuangan (distress) yang berpotensi mengalami kebangkrutan.

2. Nilai $1,23<Z<2,9$ artinya perusahaan dalam kondisi grey area sehingga kondisi ini tidak dapat dikatan sehat atupun kesulitan keuangan (distress).

3. Nilai $Z>2,9$ artinya perusahaan dalam kondisi sehat.

\section{Model Altman Modfikasi (1995)}

Altman melakukan penelitian kembali pada tahun 1995 tentang potensi kebangkrutan perusahaan-perusahaan selain perusahaan manufaktur yang go publik dan yang bukan go public (Harlen dkk, 2019:82). Sehingga Altman melakukan pengembangan menjadi model Altman modifikasi yang dinilai sangat fleksibel karena dapat digunakan untuk berbagai jenis bidang usaha perusahaan yang sedang berkembang seperti Indonesia (Rudianto dalam Harlen dkk, 2019:82). Berkaitan dengan Rumus Z-score model Altman modifikasi melakukan eliminasi terhadap variabel X5 yaitu penjualan terhadap total aset karena rasio ini bervariatif pada industri yang ukuran asetnya memiliki perbedaan.

Altman Revisi menggunakan rumus sebagai berikut:

$\mathrm{Z}=6,56 \mathrm{X}_{1}+3,26 \mathrm{X}_{2}+6,72 \mathrm{X}_{3}+1,05 \mathrm{X}_{4}$

Keterangan:

$\mathrm{X}_{1}=$ Working Capital / Total Asset

$\mathrm{X}_{2}=$ Retained Earnings / Total Asset

$\mathrm{X}_{3}=$ Earning Before Interest And Taxes / Total Asset

$\mathrm{X}_{4}=$ Book Value Of Equity / Book Value Of Total Debt

Analisa Altman Z-score terbagi menjadi tiga tingkatan. Hasil analisa dengan nilai cut off diperoleh sebagai berikut:

1. Nilai $Z<1,1$ artinya perusahaan mengalami kesulitan keuangan (distress) yang berpotensi mengalami kebangkrutan.

2. Nilai $1,1<\mathrm{Z}<2,6$ artinya perusahaan dalam kondisi grey area sehingga kondisi ini tidak dapat dikatan sehat atupun kesulitan keuangan (distress).

3. Nilai $Z>2,6$ artinya perusahaan dalam kondisi sehat. 


\section{Model Springate}

Model yang dikembangkan pada tahun1978 oleh Gorgon L.V. Springate. Model Springate merupakan model rasio yang menggunakan multiple discriminat analysis (MDA).

Springate menggunakan rumus sebagai berikut:

$\mathrm{S}=1,03 \mathrm{~A}+3,07 \mathrm{~B}+0,66 \mathrm{C}+0,4 \mathrm{D}$

Keterangan:

$\mathrm{A}=$ Modal Kerja / Total Harta

$\mathrm{B}=$ Pendapatan Sebelum Bunga dan Pajak / Total Harta

$\mathrm{C}=$ Pendapatan Sebelum Pajak / Kewajiban Lancar

$\mathrm{D}=$ Penjualan / Total Harta

Dari hasil perhitungan Springrate, model ini memiliki nilai cut off 0,869 , apabila memiliki nilai lebih dari 0,869 maka perusahaan dapat dikategorikan sehat, tetapi jika nilai kurang dari 0,869 maka perusahaan dapat dikategorikan bangkrut dijelaskan oleh Putra dan ferlina (dalam Sari dan Yunita, 2019:71).

\section{Model Grover}

Model Grover merupakan model yang diciptakan Jeffrey S. Grover dengan melakukan pendesaian dan penilaian ulang pada model Altman Z-score (Prihanthinin dan Sari dalam Gunawan, dkk 2017:120).

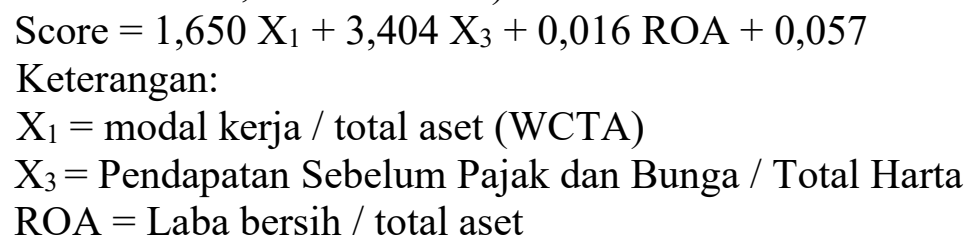

Model grover mengklasifikasikan perusahaan menjadi dua kategori yaitu sehat dan bangkrut, perusahaan kategori bangkrut memiliki skor kurang dari atau sama dengan -0,02 (skor $\leq$ 0,02 ), sedangkan perusahaan kategori sehat yang memiliki skor lebih atau sama dengan 0,01 (Skor $\geq 0,01$ ) yang dijelaskan Pakdaman (dalam Loppies, dkk 2020).

\section{Rasio Keuangan}

Rasio keuangan adalah kegiatan membandingkan angka-angka yang terdapat dalam laporan keuangan dengan cara membagi angka yang satu dengan angka yang lainnya (Kasmir, 2017:104). Rasio keuangan merupakan alat yang digunakan untuk melihat sejauh mana keuangan perusahaan memberikan kontribusinya, sehingga dapat terlihat kondisi perusahaan yang bersangkutan. Jadi rasio keuangan merupakan suatu kegiatan membandingkan angkaangka yang terdapat pada laporan keuangan dengan cara membagi angka yang satu dengan angka yang lainnya. Perbandingan dapat dilakukan dengan cara membandingkan satu pos laporan keuangan dengan pos lainnya yang memiliki hubungan yang relevan dan signifikan (Harahap, 2011:297).

\section{Penelitian Terdahulu}

Winaya et al., (2020) melakukan Analisis Altman Z-Score dan Zmijewski Prediksi Kebangkrutan Sub Sektor Telekomunikasi yang terdaftar di Bursa Efek Indonesia tahun20162018. Sampel yang digunakan pada penelitian ini 5 perusahaan dengan menggunakan seluruh perusahaan laporan tahunan periode 2016-2018. Hasil analisis subsektor telekomunikasi yang diprediksi akan mengalami kebangkrutan melalui analisis Altman Z-Score dan Zmijewski. Sehingga dapat ditarik kesimpulan masih banyaknya perusahaan yang masih belum mampu mengelola perusahaannya terkhusus pada bidang keuangan. 
Herlen dkk (2019) melakukan analisis penggunaan model Altman Z-Score untuk memprediksi potensi kebangkrutan pada perusahaan sub sektor pertambangan minyak dan gas bumi yang terdaftar di BEI pada 2012-2016. Sampel yang digunakan pada penelitian ini terdiri dari 7 perusahaan sub sektor pertambangan minyak dan gas bumi. Hasil perhitungan Altman Z-Score diperoleh hasil bahwa satu perusahaan yang diprediksi sehat, empat perusahan rawan bangkrut apabila tidak dilakukan tindakan pencegahan yang tepat, 2 perusahaan yang berpotensi bangkrut pada tahun berikutnya apabila tidak dilakukan pencegahan yang tepat.

Kakkaohe dan Pontoh (2017) melakukan analisis model Altman Z-Score untuk memprediksi kebangkrutan pada perusahaan manufaktur sektor industri barang konsumsi yang terdaftar di BEI pada 2010-2014. . Sampel yang digunakan pada penelitian ini terdiri 5 dari 21 perusahaan industri barang konsumsi, teknik pengambilan sampel adalah nonprobability samplin. Berdasarkan hasil perhitungan menggunakan model Altman Z-Score perusahaan berindikasi dalam keadaan baik. Terdapat beberapa perusahaan yang terindikasi kurang sehat atau grey area namun peningkatan penjualan selalu terjadi.

Pekerti dan Yovita (2019) pengaplikan model Altman Z-Score pada perusahaan agrikultur di Bursa Efek Indonesia tahun 2010-2017. Sampel yang digunakan pada penelitian ini terdiri dari sepuluh perusahaan agrikultur. Berdasarkan hasil perhitungan menggunakan model Altman Z-Score perusahaan berindikasi empat perusahaan berada pada resiko kebangkrutan, satu perusahaan berada pada kondisi grey area dan 5 perusahaan lainnya berada pada kondisi yang sehat. Banyaknya model prediksi kebangkrutan yang ada, investor lebih memilih model Altman Z-Score untuk membantu pengambilan keputusan di pasar modal.

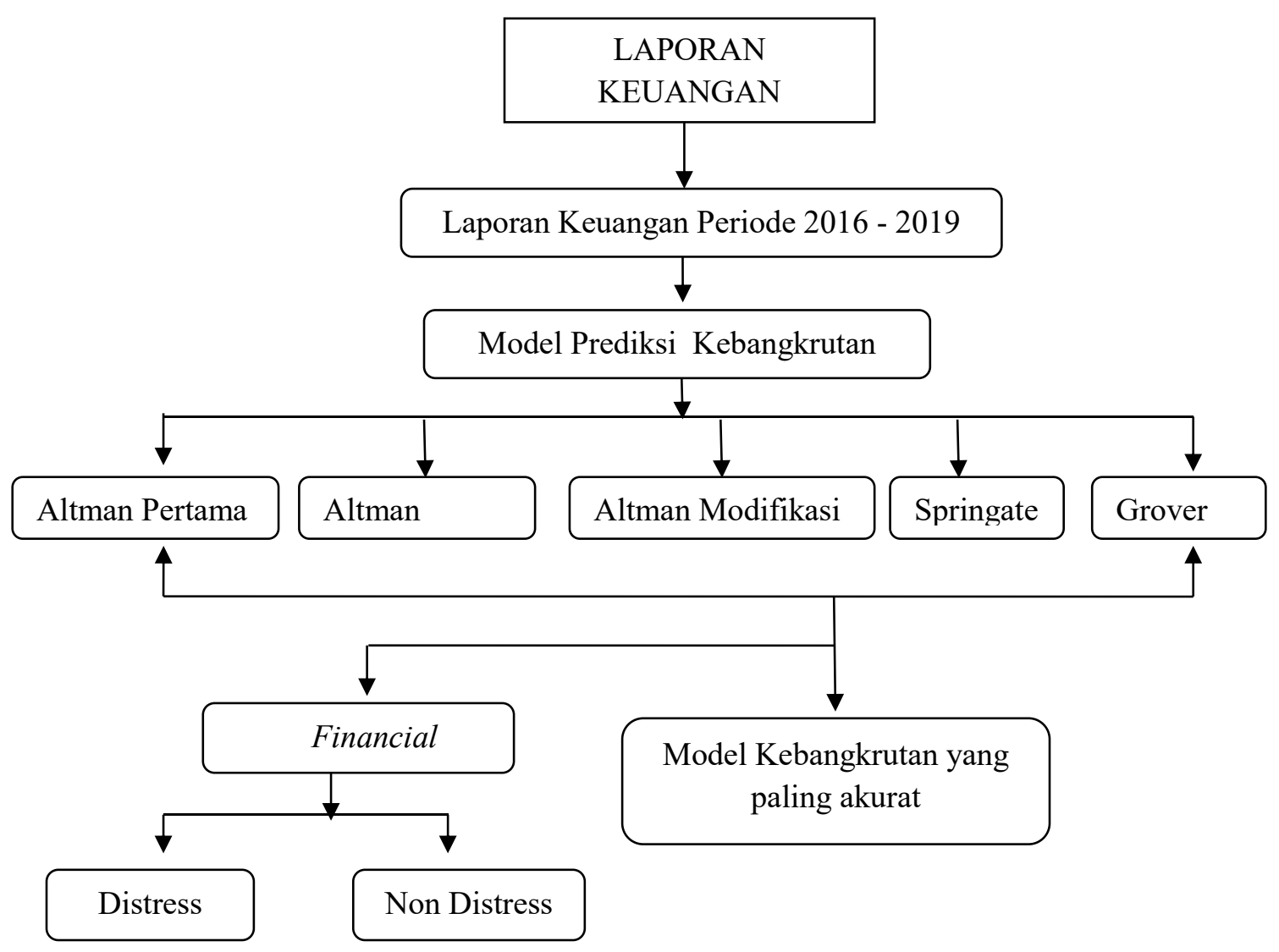

Gambar 1 Kerangka Penelitian 


\section{METODE PENELITIAN \\ Jenis Penelitian}

Jenis penelitian yang digunakan pada penelitian ini adalah deskriptif kuantitatif. Menurut Nasir, 2002 (dalam Ajad Rukajat, 2018:1) metode deskriptif merupakan metode dalam penelitian status sekelompok manusia, objek, kondisi, sistem pemikiran atau suatu peristiwa masa sekarang. Penelitian ini bertujuan untuk membuat deskripsi, gambaran, lukisan yang sitematis, faktual akurat mengenai fakta-fakta, sifat-sifat serta hubungan antar fenomena ang diselidiki.

\section{Jenis dan Sumber Data}

Jenis data yang digunakan adalah data kuantitatif yang berupa data sekunder berbentuk angka-angka yang bersumber dari laporan keuangan tahunan perusahaan yang menjadi sampel penelitian. Penelitian ini menggunakan data yang bersumber dari laporan keuangan tahunan masing-masing perusahaan food and beverages pada periode 2016 hingga 2019. Data laporan keuangan perusahaan diakses dan diunduh melalui website Bursa Efek Indonesia www.idx.co.id dan factbook, data lainnya diperoleh dari jurnal-jurnal dan literatur ilmiah yang terkait.

\section{Populasi dan Sampel}

Populasi dalam penelitian ini adalah perusahaan manufaktur sub sektor food and beverages yang terdaftar pada Bursa Efek Indonesia. Sampel dalam penelitian ini adalah perusahaan sub sektor food and beverages yang memberikan kontribusi sebesar 36,4 persen terhadap Produk Domestik Bruto (PDB) manufaktur. Teknik pengambilan sampel yang digunakan dalam penelitian ini adalah purposive sumpling.

\section{Metode Analisis Data}

Model Prediksi kebangkrutan digunakan untuk menguji tingkat keakuratan perusahaan yang mengalami kondisi distress dan perusahaan yang mengalami kondisi non distress pada masing-masing metode. Selanjutnya melakukan perbandingan antara hasil prediksi dengan kondisi aktual perusahaan sampel pada tahun 2020. Rumus yang digunakan untuk menentukan hasil prediksi tersebut yaitu:

$$
\text { Hasil Prediksi }=\underline{\text { Score } 2016+\text { Score } 2017+\text { Score } 2018+\text { Score } 2019}
$$

Score yang diperoleh dari hasil prediksi kemudian dibandingkan dengan score kondisi aktual perusahaan pada tahun 2020, ketika hasil prediksi menunjukan status yang sama ( non distress, distress dan grey area) dengan kondisi aktual perusahaan tahun 2020 ( non distress, distress dan grey area), maka dikelompokan prediksi benar (kelompok 1), jika prediksi menunjukan status yang berbeda dengan kondisi aktual tahun 2020, maka dikelompokan prediksi salah (kelompok 0). Pada penelitian ini, penulis menggunakan 14 sampel perusahaan, tingkat akurasi menunjukan berapa parsen model prediksi kebangkrutan mampu memprediksi secara benar dari sampel yang ada. Rumus yang digunakan untuk menghitung tingkat akurasi yaitu:

$$
\text { Tingkat Akurasi }=\frac{\text { Jumlah Prediksi Benar }}{\text { Jumlah Sampel }} \times \quad 100 \%
$$

Selain keakuratan model yang menjadi pertimbangan tingkat error-nya. Penulis membagi error menjadi dua jenis, yaitu Type $l$ dan type 11. Type $l$ error merupakan kesalahan yang terjadi jika model memprediksi sampel tidak mengalami kondisi distress. 
Type $l l$ error merupakan kesalahan yang terjadi jika model yang memprediksi sampel mengalami kondisi distress namun kenyataannya tidak mengalami distress.

$$
\begin{aligned}
& \text { Type } 1 \text { Error }=\frac{\text { Jumlah kesalahan Type } 1}{\text { Jumlah Sampel Distress }} \times 100 \% \\
& \text { Type } 11 \text { Error }=\frac{\text { Jumlah kesalahan Type } 1}{\text { Jumlah sampel (Non Distress + Grey Area) }} \times 100 \%
\end{aligned}
$$

Kombinasi antara Type l error dan type ll Error sehingga menghasilkan tingkat error tertimbang. Rumus yang digunakan untuk menghitung Tingkat Error tertimbang yaitu:

\section{Tingkat Error Tertimbang $=$}

\section{(Error l Type x Sampel Distress) + (Error ll Type x Sampel Non Distress)}

\section{Total Sampel}

Pada uji ini, metode yang dikatakan paling akurat adalah metode yang memiliki tingkat akurasi yang paling tinggi dan memiliki error type $l$ yang rendah.

\section{HASIL DAN PEMBAHASAN}

Analisis prediksi kebangkrutan dengan menggunakan Model Altman Pertama, Altman Revisi, Altman Modifikasi, Springate dan Grover.

Tabel 1

Altman Pertama Perusahaan Makanan dan Minuman tahun 2016-2019

\begin{tabular}{clcc}
\hline No & \multicolumn{1}{c}{$\begin{array}{c}\text { Kode } \\
\text { Perusahaan }\end{array}$} & Z-Score & Rata-Rata \\
\hline 1 & AISA & $-0,7466$ & Klasifikasi \\
2 & ALTO & 0,5173 & Distress \\
3 & CEKA & 6,6669 & Non Distress \\
4 & DLTA & 6,9702 & Non Distress \\
5 & ICBP & 3,2160 & Non Distress \\
6 & INDF & 2,2554 & Grey Area \\
7 & MLBI & 4,1024 & Non Distress \\
8 & MYOR & 3,6200 & Non Distress \\
9 & PSDN & 1,8623 & Grey Area \\
10 & ROTI & 2,6380 & Grey Area \\
11 & SKBM & 2,3852 & Grey Area \\
12 & SKLT & 2,5224 & Grey Area \\
13 & STPT & 3,7142 & Non Distress \\
14 & ULTJ & 6,2721 & Non Distress \\
\hline
\end{tabular}

Sumber : data diolah tahun 2021

Hasil analisa dengan nilai cut off diperoleh sebagai berikut Nilai $\mathrm{Z}<1,8$ artinya perusahaan mengalami kesulitan keuangan (distress) yang berpotensi mengalami kebangkrutan. Nilai 1,8<Z<2,99 artinya perusahaan dalam kondisi grey area sehingga 
kondisi ini tidak dapat dikatan sehat ataupun kesulitan keuangan (distress). Nilai Z $>2,99$ artinya perusahaan dalam kondisi sehat.

Tabel 2

Altman Revisi Perusahaan Makanan dan Minuman tahun 2016-2019

\begin{tabular}{clcc}
\hline No & \multicolumn{1}{c}{ Kode } & Rata-Rata & \\
& Perusahaan & Z-Score & Klasifikasi \\
\hline 1 & AISA & $-0,6240$ & Distress \\
2 & ALTO & 0,4195 & Distress \\
3 & CEKA & 5,4659 & Non Distress \\
4 & DLTA & 5,0714 & Non Distress \\
5 & ICBP & 2,5231 & Grey Area \\
6 & INDF & 1,8294 & Grey Area \\
7 & MLBI & 3,7044 & Non Distress \\
8 & MYOR & 2,9402 & Grey Area \\
9 & PSDN & 1,8385 & Grey Area \\
10 & ROTI & 2,0296 & Grey Area \\
11 & SKBM & 2,0009 & Grey Area \\
12 & SKLT & 2,2056 & Grey Area \\
13 & STPT & 2,9419 & Non Distress \\
14 & ULTJ & 4,6927 & Non Distress \\
\hline
\end{tabular}

Sumber:data diolah tahun 2021

Hasil analisa dengan nilai cut off diperoleh sebagai berikut Nilai $Z<1,23$ artinya perusahaan mengalami kesulitan keuangan (distress) yang berpotensi mengalami kebangkrutan. Nilai $1,23<Z<2,9$ artinya perusahaan dalam kondisi grey area sehingga kondisi ini tidak dapat dikatan sehat ataupun kesulitan keuangan (distress). Nilai $\mathrm{Z}>2,9$ artinya perusahaan dalam kondisi sehat.

Tabel 3

Altman Modifikasi Z-Score Perusahaan Makanan dan Minuman tahun 2016-2019

\begin{tabular}{|c|c|c|c|}
\hline \multirow{2}{*}{ No } & \multirow{2}{*}{$\begin{array}{c}\text { Kode } \\
\text { Perusahaan }\end{array}$} & \multicolumn{2}{|c|}{ Rata-Rata } \\
\hline & & Z-Score & Klasifikasi \\
\hline 1 & AISA & $-7,1290$ & Distress \\
\hline 2 & ALTO & 0,2814 & Distress \\
\hline 3 & CEKA & 9,5516 & Non Distress \\
\hline 4 & DLTA & 15,5742 & Non Distress \\
\hline 5 & ICBP & 5,6925 & Non Distress \\
\hline 6 & INDF & 3,3445 & Non Distress \\
\hline 7 & MLBI & 5,1409 & Non Distress \\
\hline 8 & MYOR & 6,3566 & Non Distress \\
\hline 9 & PSDN & 0,0691 & Distress \\
\hline 10 & ROTI & 4,8213 & Non Distress \\
\hline 11 & SKBM & 2,7318 & Grey Area \\
\hline 12 & SKLT & 2,4063 & Grey Area \\
\hline 13 & STPT & 6,0507 & Non Distress \\
\hline 14 & ULTJ & 11,9136 & Non Distress \\
\hline
\end{tabular}

Sumber:data diolah tahun 2021 
Hasil analisa dengan nilai cut off diperoleh sebagai berikut Nilai $Z<1,1$ artinya perusahaan mengalami kesulitan keuangan (distress) yang berpotensi mengalami kebangkrutan. Nilai $1,1<Z<2,6$ artinya perusahaan dalam kondisi grey area sehingga kondisi ini tidak dapat dikatan sehat ataupun kesulitan keuangan (distress). Nilai $Z>2,6$ artinya perusahaan dalam kondisi sehat.

Tabel 4

Springate Perusahaan Makanan dan Minuman tahun 2016-2019

\begin{tabular}{clcc}
\hline No & Kode Perusahaan & Z-Score & Rata-Rata \\
\hline 1 & AISA & $-2,0822$ & Klasifikasi \\
2 & ALTO & $-0,1020$ & Distress \\
3 & CEKA & 2,5951 & Distress \\
4 & DLTA & 3,5406 & Non Distress \\
5 & ICBP & 1,4286 & Non Distress \\
6 & INDF & 0,9165 & Non Distress \\
7 & MLBI & 2,9876 & Non Distress \\
8 & MYOR & 1,8495 & Non Distress \\
9 & PSDN & 0,7373 & Distress \\
10 & ROTI & 1,0736 & Non Distress \\
11 & SKBM & 0,6971 & Distress \\
12 & SKLT & 0,9522 & Non Distress \\
13 & STPT & 1,6349 & Non Distress \\
14 & ULTJ & 2,4398 & Non Distress \\
\hline
\end{tabular}

Sumber:data diolah tahun 2021

Hasil perhitungan Springrate, model ini memiliki nilai cut off 0,869 , apabila memiliki nilai lebih dari 0,869 maka perusahaan dapat dikategorikan sehat, tetapi jika nilai kurang dari 0,869 maka perusahaan dapat dikategorikan bangkrut dijelaskan oleh Putra dan ferlina (dalam Sari dan Yunita, 2019:71).

Tabel 5

Grover Perusahaan Makanan dan Minuman tahun 2016-2019

\begin{tabular}{clcc}
\hline No & \multicolumn{1}{c}{$\begin{array}{c}\text { Kode } \\
\text { Perusahaan }\end{array}$} & Z-Score & Rata-Rata \\
\hline 1 & AISA & $-3,1987$ & Klasifikasi \\
2 & ALTO & $-0,0884$ & Distress \\
3 & CEKA & 1,3956 & Distress \\
4 & DLTA & 2,3116 & Non Distress \\
5 & ICBP & 0,9262 & Non Distress \\
6 & INDF & 0,5362 & Non Distress \\
7 & MLBI & 1,9067 & Non Distress \\
8 & MYOR & 1,2884 & Non Distress \\
9 & PSDN & 0,0864 & Distress \\
10 & ROTI & 0,6998 & Non Distress \\
\hline
\end{tabular}




\begin{tabular}{llll}
\hline 11 & SKBM & 0,3229 & Non Distress \\
12 & SKLT & 0,3934 & Non Distress \\
13 & STPT & 0,8933 & Non Distress \\
14 & ULTJ & 1,4539 & Non Distress \\
\hline
\end{tabular}

Sumber:data diolah tahun 2021

Model grover mengklasifikasikan perusahaan menjadi dua kategori yaitu sehat dan bangkrut, perusahaan kategori bangkrut memiliki skor kurang dari atau sama dengan -0,02 (skor $\leq-0,02$ ), sedangkan perusahaan kategori sehat yang memiliki skor lebih atau sama dengan 0,01 (Skor $\geq 0,01$ ) yang dijelaskan Pakdaman (dalam Loppies, dkk 2020).

\section{Perbedaan Hasil Prediksi}

Tabel 6

Hasil Perhitungan Perusahaan Bangkrut, Tidak Bangkrut dan Grey Area model Altman Pertama, Altman Revisi, Altman Modifikasi, Springate dan Grover

\begin{tabular}{clcccc}
\hline \multirow{2}{*}{ Model } & \multicolumn{1}{c}{ Keterangan } & $\mathbf{2 0 1 6}$ & $\mathbf{2 0 1 7}$ & $\mathbf{2 0 1 8}$ & $\mathbf{2 0 1 9}$ \\
\hline \multirow{2}{*}{ Altman } & Bangkrut & 2 & 2 & 1 & 2 \\
Pertama & Grey Area & 7 & 6 & 6 & 3 \\
& Tidak Bangkrut & 5 & 6 & 7 & 9 \\
Altman & Bangkrut & 1 & 2 & 1 & 1 \\
Revisi & Grey Area & 9 & 7 & 8 & 5 \\
& Tidak Bangkrut & 4 & 5 & 5 & 8 \\
Altman & Bangkrut & 1 & 2 & 3 & 2 \\
Modifikasi & Grey Area & 2 & 2 & 1 & 0 \\
& Tidak Bangkrut & 11 & 10 & 10 & 12 \\
Springate & Bangkrut & 3 & 5 & 5 & 3 \\
& Tidak Bangkrut & 11 & 9 & 9 & 11 \\
\multirow{2}{*}{ Grover } & Bangkrut & 1 & 2 & 3 & 2 \\
& Tidak Bangkrut & 13 & 12 & 11 & 12 \\
\hline
\end{tabular}

Sumber:data diolah tahun 2021

Berdasarkan hasil perhitungan dengan menggunakan model Altman Pertama, Altman Revisi, Alman Modifikasi, Springate dan grover terdapaat perbedaan hasil yang disebabkan adanya nilai-nilai rasio keuangan yang berbeda pada masing-masing model. Model Altman Pertama, Altman Revisi, Alman Modifikasi, Springate dan grover memberikan penilaian yang berbeda terhadap 14 perusahaan food and beverages yang terdaftar pada Bursa Efek Indonesia, dikarenakan rasio yang digunakan untuk mengukur prediksi kebangkrutan keuangan pada perusahaan berbeda-beda. 
Hasil Keakuratan Model Prediksi

Tabel 7

Perbandingan Akurasi dan Error Model Prediksi

\begin{tabular}{clrrrr}
\hline \multirow{2}{*}{ Peringkat } & Model & $\begin{array}{c}\text { Tingkat } \\
\text { Akurasi }\end{array}$ & $\begin{array}{c}\text { Tingkat Error } \\
\text { Tertimbang }\end{array}$ & $\begin{array}{c}\text { Type I } \\
\text { error }\end{array}$ & \multicolumn{1}{c}{$\begin{array}{c}\text { Type II } \\
\text { error }\end{array}$} \\
& & & & & \\
\hline 1 & Altman Pertama & $64,29 \%$ & $35,71 \%$ & $0,00 \%$ & $41,67 \%$ \\
2 & Altman Revisi & $71,43 \%$ & $28,57 \%$ & $0,00 \%$ & $3,33 \%$ \\
3 & Altman Modifikasi & $85,71 \%$ & $14,29 \%$ & $0,00 \%$ & $18,18 \%$ \\
4 & Springate & $92,86 \%$ & $7,14 \%$ & $3,33 \%$ & $0,00 \%$ \\
5 & Grover & $85,71 \%$ & $14,29 \%$ & $3,33 \%$ & $8,33 \%$ \\
\hline
\end{tabular}

Sumber : data diolah tahun 2021

Berdasarkan Tabel 7, model springate memiliki tingkat akurasi dengan nilai 92,86\%, hal ini menginterpretasikan bahwa model ini memiliki tingkat akurasi yang paling tinggi dalam memprediksi perusahaan yang mengalami kondisi distress maupun non distress pada sub sektor food and beverages periode 2016-2019, model Altman Modifikasi dan Model Grover memiliki tingkat akurasi yang sama yaitu sebesar 85,71\%, Model Altman Revisi memiliki tingkat akurasi 71,43\%, sedangkan Model Altman Pertama memiliki tingkat akurasi yang paling rendah sebesar $64,29 \%$.

Error $l$ Type, Model Altman Pertama, Altman Revisi Altman Modifikasi yang memiliki tingkat error terendah sebesar $0,00 \%$, Springate dan gover yang memiliki tingkat error sebesar 3,33\%. hal ini menginterpretasikan kedua model memiliki tingkat akurasi yang sama, namun model Altman Modifikasi ini cendrung memiliki tingkat kesalahan lebih kecil dalam memprediksi perusahaan yang mengalami kondisi distress.

Error ll Type, model Springate memiliki Error yang paling rendah sebesar 0,00\% dibandingkan Grover sebesar 8,33\%, Altman Modifikasi sebesar 18,18\%, Altman Revisi sebesar 3,33\% dan Altman Pertama sebesar 41,67\%. Hal ini tentu menasa unjukan Model Springate memiliki tingkat kesalahan yang kecil dalam memprediksi perusahaan yang mengalami distress dan non distress. Jika kita urutkan berdasarkan keakuratan dan error 1 type model yang terbaik adalah Springate, Altman Modifikasi, Grover, Altman Revisi, Altman Pertama.

\section{SIMPULAN DAN SARAN}

\section{Simpulan}

Berdasakan dari hasil dan pembahasan dan yang telah diuraikan diatas sehingga dapat diambil kesimpulkan sebagai berikut:

1. Hasil prediksi menggunakan model Altman Pertama 2 perusahaan mengalami distress, 5 perusahaan berada pada kondisi Grey Area, dan 7 perusahaan berada pada kondisi non ditress. Altman Revisi 2 perusahaan mengalami distress, 7 perusahaan berada pada kondisi Grey Area, dan 5 perusahaan berada pada kondisi non ditress. Altman Modifikasi 3 perusahaan mengalami distress, 2 perusahaan berada pada kondisi Grey Area, dan 9 perusahaan berada pada kondisi non ditress. Springate 3 perusahaan mengalami distress dan 11 perusahaan berada pada kondisi non ditress. Grover 2 perusahaan mengalami distress dan 12 perusahaan berada pada kondisi non ditress.

2. Hasil pengujian menunjukkan tidak terdapat perbedaan yang signifikan antara model Altman Pertama, Altman Revisi, Altman Modifikasi, Springate dan Grover dalam memprediksi tingkat kebangkrutan perusahaan sub sektor food and beverages yang terdaftar pada Bursa Efek Indonesia. Model Altman Pertama menyatakan rata-rata 
terdapat 2 perusahaan bangkrut selama 4 tahun yaitu 14,29\%, model Altman Revisi menyatakan rata-rata terdapat 2 perusahaan bangkrut selama 4 tahun yaitu 14,29\%, model Altman Modifikasi menyatakan rata-rata terdapat 3 perusahaan bangkrut selama 4 tahun yaitu $21,43 \%$, Model Springate menyatakan rata-rata terdapat 3 perusahaan bangkrut selama 4 tahun yaitu $21,43 \%$ dan Grover menyatakan rata-rata terdapat 2 perusahaan bangkrut selama 4 tahun yaitu 14,29\%.

3. Terdapat perbedaan Score dinilai dari tingkat akurasi antara model Altman Pertama, Altman Revisi, Altman Modifikasi, Springate dan Grover dalam memprediksi kebangkrutan. Perbedaan dapat dilihat melalui uji keakuratan model prediksi dan tingkat Errornya, pada penelitian ini model springate memiliki tingkat akurasi paling tinggi dengan nilai 92,86\% dengan error 1 type 3,33\% dan error 11 type 0,00\%, model Altman Modifikasi memiliki tingkat akurasi dengan nilai 85,71\% dengan error 1 type $0,00 \%$ dan error 11 type 18,18\%, model Grover memiliki tingkat akurasi dengan nilai 85,71\% dengan error 1 type 3,33\% dan error 11 type 8,33\%, model Altman Revisi memiliki tingkat akurasi dengan nilai 71,43\% dengan error 1 type $0,00 \%$ dan error 11 type 3,33\%, dan model Altman Pertama memiliki tingkat akurasi dengan nilai 64,71\% dengan error 1 type $0,00 \%$ dan error 11 type $41,67 \%$.

\section{Saran}

Berdasarkan hasil penelitian yang telah disajikan maka peneliti menyampaikan saransaran untuk penelitian selanjutnya sebagai berikut:

1. Menambah model prediksi kebangkrutan menjadi lebih dari 5 model seperti menambahkan model Zavgen, Fulmer dan Zmijewski dan sebagainya.

2. Pada penelitian selanjutnya, diharapkan untuk menambah periode penelitian dan melakukan penelitian pada sektor lain seperti, Pertanian, Pertambangan, industri dasar dan kimia dan lain sebagainya

\section{DAFTAR PUSTAKA}

Dwijayanti, Fatricia Febrina. Penyebab, Dampak, dan Prediksi dari Financial Distress Serta Solusi untuk Mengatasi Financial Distress. Jurnal Akuntansi Kontemporer. Vol. 2, No. 2, hal 191-205.

Gamayuni, Rindu Rika. 2009. Berbagai Alternatif Model Prediksi Kebangkrutan. JAKI. Vol.14, No. 1.

Hadijah, Siti \& Agustina Kurniasih. 2014. Analsis Prediksi Kebangkrutan Perusahaan Manufaktur Sub Sektor Food and beverages Yang Terdaftar di Bursa Efek Indonesia (BEI). Jurnal Ilmu Ekonomi dan Sosial. No. 2, hlm 302-310.

Herlen, Yudha Samodra \& dkk (2019). Analisis Penggunaan Model Altman (Z-score) Untuk Memprediksi Potensi Kebangkrutan (Studi Kasus Pada Perusahaan Sub Sektor Pertambangan Minyak dan Gas Bumi Yang Terdaftar di BEI pada 2012-2016). Jurnal Administrasi dan Bisnis. Vol. 66, No. 1.

Kakauhe, Anastasya Claudio Indri \& winston Pontoh . 2017. Analsis Prediksi Model Altman (Z-score) Dalam Mengukur Kinerja Keuangan Untuk Memprediksi Kebangkrutan Pada Perusahaan Manufaktur Sektor Industri Barang Konsumsi Bursa Efek Indonesia (BEI) Periode 2010-2014. Vol. 06, No. 01, Hal 18-27.

Loppies, Lilian Sonya \& dkk. 2020. Bankruptcy Prediction Analysis Using Altman Z-score, Grover Model and Springrate S-Score ( A study in Retail Companies listed in Indonesia Stock Exchange 2014-2018 Period). Journal of Critical Reviews. Vol. 7, No. 08 . 
Noviandini Nurul \& Mirza Safitri Agatha Putri. 2018. Analisis Altman Z-score Untuk Memprediksi Kebangkrutan Pada Perusahaan Maufaktur Sektor Barang Konsumsi di Indonesia.

Prihadi, Toto. 2019. Analisis Laporan Keuangan. Jakarta: PT Gramedia Pustaka Utama.

Rukajat, Ajad. 2018. Pendekatan Penelitian Kuantitatif. Deepublish: CV Budi Utama. Hlm. 1.

Salatin, Aswinda \& dkk. 2013. Penerapan Model Altman (Z-score) Untuk Memprediksi Kebangkrutan Pada Industri Tekstil dan Produk Tekstil Terdaftar di BEI 2009-2011. Jurnal Administrasi Bisnis. Vol. 6, No. 2.

Sari, Mauli Permata \& Irni Yunita. 2019. Analisis Prediksi Kebangkrutan dan Tingkat Akurasi Model Springrate, Zmijewski, dan Grover Pada Perusahaan Sub Sektor Logam dan Mineral Lainnya Yang Terdaftar di Bursa Efek IndonesiaTAhun 20122016. Jurnal Ilmiah Manajemen. Vol. 7, No. 1.

Sari, Riska Febri Amarista \& Sri Rahayu. 2018. Pengaruh Perputaran Persediaan dan Rasio Hutang Terhadap Profitabilitas. e-Proceeding of Management. Vol. 5, No. 2. 